\title{
The Integration of Intercultural Education into Teaching English: What Vietnamese Teachers Do and Say
}

\section{Chau Thi Hoang Hoa}

$\mathrm{PhD}$. candidate at University of Foreign Languages, Hue University, Vice Director of International Collaboration Office, Tra Vinh University, Vietnam, cthhoa@tvu.edu.vn

Truong Vien

Assoc. Prof., University of Foreign Languages, Hue University, Vietnam, truongviensp@gmail.com

To enable the Vietnamese youth to join the international workforce during ASEAN integration, teaching English in general education has undertaken a reform with the aim of intercultural communicative competence instead of communicative competence. Since building learners' intercultural communicative competence requires their personal engagement in social interaction, teachers should follow a proper approach to activate students' participation in intercultural communication. This research studied to what extent upper secondary school teachers perceived and practiced intercultural integration prior the educational reform. Data collected from 101 participating teachers through questionnaires and open-ended questions proved that (1) teachers had good understanding of intercultural integration, but (2) they rarely conducted intercultural activities in practices, and (3) teachers' graduate education, not international experience or coursebook teaching, had a positive impact on their intercultural teaching practices. The findings suggested that educational management should be consistent with the progressive reform through the synchronization of all curricular factors towards intercultural education, and teachers should be oriented with intercultural teaching pedagogy to conduct suitable activities to develop students' intercultural communicative competence.

Keywords: educational reform, intercultural communicative competence, intercultural integration, teachers' perceptions and practices, teaching English

\section{INTRODUCTION}

Intercultural competence (IC) is essential for global citizens in the 21 st century, the era of integration (Stiftung \& Cariplo, 2008). The roles of culture teaching and intercultural education in contemporary time are confirmed and emphasized (Arslangilay, 2018;

Citation: Chau, T. H. H., \& Truong, V. (2019). The Integration of Intercultural Education into Teaching English: What Vietnamese Teachers Do and Say. International Journal of Instruction, 12(1), 441-456. https://doi.org/10.29333/iji.2019.12129a 
Byram \& Kramsch, 2008; Hofstede, 1991; Tran \& Dang, 2014; Tran \& Duong, 2015). In the same line, Vietnamese language-in-education policy has shown an increasing interest in developing IC for learners, which was considered as an integral part of the educational reform in foreign language teaching (Hoang, 2016; Le, 2004; Nunan, 2004). In fact, since 2014, the experimental English coursebook version with a wealth of intercultural content has been introduced to gradually replace the current coursebooks. In an evaluation of the experimental English coursebook (grade 10, volume 1), Lai (2016) proved the proportion of home, target language, and international culture was $51 \%, 31 \%$, and $18 \%$ respectively. In the transitional period, it is important to explore teachers' perceptions and practices of intercultural integration and their supporting factors, namely teachers' education, teachers' intercultural experience, and coursebook teaching.

\section{REVIEW OF LITERATURE}

\section{Concepts and Principles}

In the history of language teaching, Communicative Language Teaching has gained a remarkable position with the main goal to develop learners' communicative competence (CC). CC has been defined differently and partially in relation to IC. In fact, Canale and Swain (1981), Celce-Murcia et al. (1995), and Van Ek (1986) concurrently approved the social and cultural factors of CC. Noticeably, Van Ek (1986) introduced six elements of $\mathrm{CC}$ : linguistic, sociolinguistic, discourse, strategic, sociocultural, and social competence. Of them, sociocultural and social competence involve motivation, attitude, tolerance, and empathy, which have been recognized as components of IC.

In literature, two prominent models of IC have been introduced by Byram (1997) and Fantini (2006). Byram (1997) developed an IC model constituted from five interrelated components, known as the five - savoirs: (1) savoir être - attitude, (2) savoirs knowledge, (3) savoir comprendre - skills to interpret and relate, (4) savoir apprendre/faire - skills to discover and interact and (5) savoir s' engager - critical cultural awareness. Fantini (2006) proposed another model of intercultural communicative competence (ICC), including multiple constituents and four IC dimensions, namely, knowledge, (positive) attitudes, skills, and awareness. In this framework, the four elements are arranged in a spiral and dynamic circle. Due to the dynamicity of Fantini's framework (2006), it has been adopted in specifying IC objectives and activities in intercultural language education.

Of popular approaches for intercultural teaching, culture as practice was originated from dynamic view of culture (Ho, 2011; Newton, Yates, Shearn, \& Nowitzki, 2010). It has been widely accepted for developing skills to communicate and behave right in the target language culture, but it is blamed for ignoring the roles of learners' home culture (Crozet, Liddicoat \& Lo Bianco, 1999). Therefore, Crozet et al. (1999) proposed intercultural language teaching approach to promote students' acquisition of IC through intercultural language activities, namely exploring cultures and comparing home with target language culture. However, both approaches ignored the interculturality of intercultural communication. Embracing the ideas of practicing culture and acquiring 
culture, this study advocates an approach for intercultural integration or intercultural teaching to develop leaners' IC though their personal engagement in social intercultural communication in form of intercultural (language) activities (Byram, 2006; Deardorff, 2006; Liddicoat and Crozet, 1997; Newton, 2016; Newton et al. 2010) with the following principles:

- Intercultural teaching should be included in language lessons, not as a lesson by itself, but with a balance of cultural and linguistic focus.

- Intercultural teaching should be both implicit and explicit with clearly stated intercultural outcomes.

- Intercultural teaching should foster learners' acquiring and learning process.

- Intercultural teaching should take the diversity of learners and contexts into account with variety of intercultural language activities.

- Intercultural teaching should aim to develop learners' ICC rather than native-speaker competence.

In light of dynamic view of IC and principles of intercultural teaching, teachers' perceptions and practices are specified and discussed.

\section{Previous Studies}

A number of related studies in Europe (Lázár, 2007; Gönen \& Sağlam, 2012; Sercu et al., 2005) and in Asia (Chau and Truong, 2018; Ho, 2011; Nguyen, 2013; Zhou, 2011) are found relevant to this study as they investigate teachers' perceptions and practices of intercultural integration from the view of dynamic culture. Some similarities among those studies can be found. First, teachers' perceptions and practices, which are defined as what teachers think and do (Borg, 2003) were studied in parallel. Second, in many contexts, regardless of intercultural or target language environments, teachers had good intercultural teaching perceptions, but they did not frequently implement intercultural teaching in practice.

Teachers' perceptions of intercultural integration have been studied by Chau \& Truong (2018), Gönen \& Sağlam (2012), Nguyen (2013), Sercu et al. (2005), and Zhou (2011). It was generally proven that teachers had good perceptions of intercultural integration. They believed that the objectives of intercultural integration were to develop both linguistic and intercultural competence and approved the explicit incorporation of teaching culture into teaching language (Chau \& Truong, 2018; Gönen \& Sağlam, 2012; Sercu et al., 2005; Zhou, 2011). However, intercultural teaching was inferior to language teaching and focused on developing learners' intercultural knowledge (Gönen \& Sağlam, 2012; Sercu et al., 2005; Zhou, 2011). Notably, Nguyen (2013) confirmed that teachers were not fully aware of their responsibilities to deal with intercultural integration in teaching English as a foreign language (EFL). Besides, Chau \& Truong (2018) pinpointed that there existed the ignorance of intercultural objectives and well as the discrepancy between teachers' perceptions and practices of intercultural integration. In general, teachers were positive to the integration of cultures into teaching EFL, but they still had different attitudes towards the balance of language and culture and their responsibility awareness. 
From reflection of teachers' intercultural teaching practices or classroom observations, Chau and Truong (2018), Gönen and Sağlam (2012), Ho (2011), Lázár (2007), Nguyen (2013), Sercu et al. (2005), and Zhou (2011) confirmed that teachers did not deal with intercultural integration properly. Intercultural instruction was mainly knowledgefocused and teacher-centered (Chau \& Truong, 2018; Gönen \& Sağlam, 2012; Zhou, 2011). Besides, culture was treated as an add-on or a time-filler to a language lesson (Lázár, 2007; Ho, 2011). In addition, in Vietnam, Chau \& Truong (2018), Ho (2011), and Nguyen (2013) concurrently found that intercultural teaching was accidental, implicit, and topic dependent because they just followed the coursebooks. For the above reasons, it is concluded that intercultural integration was not properly implemented.

In terms of content, the common discussion was what cultures were integrated: foreign culture or home culture, "big C" culture (civilization) or "small c" culture (behaviours, practices, values, and discourse structures). Gönen \& Sağlam (2012) and Sercu et al. (2005) focused on the dominance of English speaking cultures. Other studies proved teachers' preferences of cultural diversity, covering home, target language, and other cultures (Chau \& Truong, 2018; Ho, 2011; Lázár, 2007; Nguyen, 2013; Zhou, 2011). More specifically, Lázár (2007) found that teachers were more inclined to teach "big C" culture than "small c" culture, but Ho (2011) found the opposite. The finding gaps among the mentioned studies might be attributed to the learner and participant variance and size of research population.

Supporting factors to intercultural instruction were defined by Gönen and Sağlam (2012), Lázár (2007), and Zhou (2011). Lázár (2007) proved that two factors contributing to the frequency of intercultural teaching activities were teachers' intercultural experience and teachers' training, of which the former was less overt. Focusing on teachers' education and training, Gönen and Sağlam (2012) found that teachers of English Language Teaching (ELT) and non-ELT background gave different priority to aspects of the target culture, but their practices were generally driven by the curriculum that they applied. Regarding international experience, Zhou (2011) explored that teachers' IC from international experience had meaningful impacts on their teaching beliefs and practices. As discussed, common contributing factors to teachers' intercultural teaching were their professional education, intercultural experience, IC, curriculum, and but the degree to which these factors were affected varied.

\section{METHOD}

The research combined quantitative and qualitative approaches with the use of 5-point Likert scale questionnaires and two open-ended questions. The data were collected and analysed mainly statistically based on responses from 101 EFL teachers in upper secondary schools. The participants' responses to the open-ended questions added more in-depth information to descriptive and inferential statistics.

\section{Context and Participants}

Since 2008, the Ministry of Education and Training has carried out the National Foreign Language Project 2020 (NFLP 2020) as a renovation of language in education policy from macro to micro levels (Hoang, 2016). As a part of this scheme, a new English 
curriculum, from Grade 3-12, has been introduced to teaching EFL in general education. Of the series, experimental course books for Grade 10-12 are included with intercultural content of home culture, English speaking cultures, and the other cultures to develop learners' CC and comprehensive IC (Hoang, 2016). As a part of a larger research, this study was conducted to focus on teachers' implementation of intercultural integration in the academic year 2017-2018, the midstream of NFLP 2020, when the current and experimental English coursebooks have been used simultaneously at national scale.

Target participants of this research were all (190) upper secondary school EFL teachers in Tra Vinh, a province of the Mekong Delta, Southern Vietnam. Of them, 101 teachers voluntarily joined the research by giving their responses to the questionnaires. Demographic information of participating teachers is presented in Table 1.

Table 1

Teachers' demographic information

\begin{tabular}{ll}
\hline Category & Number of participants \\
\hline Course book teaching & 28 teaching both versions, \\
(or teaching experience) & 73 teaching the current version only \\
\hline International experience & 16 been abroad at least 1 week, \\
& 85 never been abroad \\
\hline Educational degrees & 12 Master's degrees in TESOL \\
& 89 Bachelor's degrees in TESOL \\
\hline
\end{tabular}

\section{Research Instruments}

\section{The Questionnaire}

The questionnaire comprised two sections with 27 items totally focusing on teachers' perceptions and practices. The clusters and items of the questionnaire were adopted from Chau and Truong (2018). These items were organized in a 5-point Likert scale questionnaire, from strongly disagree to strongly agree for teachers' perceptions of intercultural teaching and from never to always for the frequency of intercultural language activities conducted in classes. Items were organized deliberately within each section as presented in Table 2.

Table 2

Item distribution in the questionnaire

\begin{tabular}{|c|c|c|}
\hline Focus & Clusters & Items \\
\hline \multirow{2}{*}{$\begin{array}{l}\text { Teachers' } \\
\text { perceptions }\end{array}$} & $\begin{array}{l}\text { Teachers' beliefs in the objectives } \\
\text { of intercultural integration }\end{array}$ & $\mathrm{A} 1, \mathrm{~A} 2, \mathrm{~A} 6, \mathrm{~A} 8$ \\
\hline & $\begin{array}{l}\text { Teachers' perceived practices of } \\
\text { intercultural integration }\end{array}$ & $\mathrm{A} 3, \mathrm{~A} 7, \mathrm{~A} 5, \mathrm{~A} 9, \mathrm{~A} 12, \mathrm{~A} 11, \mathrm{~A} 10$ \\
\hline \multirow{4}{*}{$\begin{array}{l}\text { Teachers' } \\
\text { practices }\end{array}$} & Teaching intercultural knowledge & B1, B2, B3 \\
\hline & Having students explore cultures & B4, B6, B7 \\
\hline & $\begin{array}{l}\text { Developing positive intercultural } \\
\text { attitudes }\end{array}$ & $\mathrm{B} 5, \mathrm{~B} 10, \mathrm{~B} 11, \mathrm{~B} 12, \mathrm{~B} 13, \mathrm{~B} 14, \mathrm{~B} 15$ \\
\hline & Developing intercultural skills & B8, B9, B16 \\
\hline
\end{tabular}


Teachers' perceptions were classified as teachers' beliefs (Item A1, A2, A6, and A8) and perceived practices (Item A3, A7, A5, A9, A10, A11, and A12); the former relating the importance and objectives of intercultural integration, the latter describing how intercultural teaching should be implemented following the principles proposed by Crozet and Liddicoat (2000), Newton (2016), and Newton et al. (2010). Intercultural teaching practices reflected by the teachers were further divided into four groups: teacher-centred activities to teach intercultural knowledge (Item B1, B2, and B3), student-centred activities to teach intercultural knowledge (Item B4, B6, and B7), activities to develop intercultural attitudes (Item B5, B10, B11, B12, B13, B14, and B15), and activities to develop intercultural skills (Item B8, B9, and B16).

As suggested by Hung, Vien and $\mathrm{Vu}$ (2018), to ensure the intelligibility and clarity, the questionnaire should be subjected to linguistic modification for the equivalence of terms in English and Vietnamese. The bilingual version was piloted to a group of 47 teachers in another province of the Mekong Delta with positive coefficient reliability for teachers' perceptions and practices $(\alpha=.872$ and .886 respectively). Cronbach coefficient alpha for scale reliability of the two sections in this study were above .70 ( $\alpha$ $=.775$ and .886 respectively).

\section{Open-ended Questions}

Each open-ended question was added right after its related parts in the questionnaire to investigate other opinions and experiences from the participating teachers in terms of intercultural teaching.

\section{Data Collection and Analysis}

The final questionnaire was sent to all upper secondary school teachers in Tra Vinh, a province in Southern Vietnam, and received 101 qualified responses. Quantitative data were analysed for mean score of each item, cluster, average mean score, mean compares of teachers' perceptions and practices within and cross groups as defined in Table 1. Qualitative data collected from open-ended questions were analysed following content analysis approach deductively and inductively, involving both classifying related contents corresponding to identified categories (Polit \& Beck, 2012) and coding, creating categories, and abstracting (Elo \& Kyngäs, 2008). Simply stated, teacher's responses were classified into pre-determined clusters as mentioned in Table 2. The responses not belonging to those clusters were re-examined and organized into new categories for interpreting.

\section{FINDINGS}

Mean scores of teachers' beliefs, perceived practices, and practices are presented in Table 3. Of the three variables, mean of teachers' beliefs is the highest $(M=4.2748$, SD $=.48927)$ and that of teachers' practices $(\mathrm{M}=2.7635, \mathrm{SD}=.46517)$ is the lowest. 
Table 3

Mean scores of teachers' beliefs, perceived practices, and practices

\begin{tabular}{lclcc}
\hline Mean & $\mathrm{N}$ & Mean & Std. Deviation & Std. Error \\
\hline Teachers' beliefs & 101 & 4.2748 & .48927 & .04868 \\
\hline Teachers' perceived practices & 101 & 3.8169 & .44703 & .04448 \\
\hline Teachers' practices & 101 & 2.7635 & .46517 & .04629 \\
\hline
\end{tabular}

Table 3 showed that teachers had very good awareness of intercultural teaching objectives, fairly good understanding of intercultural teaching but rarely conducted intercultural teaching activities in class.

\section{Results of the First Research Question}

Mean scores of the items describing teachers' beliefs are presented in Table 4. Among the 11 items, Item A1, expressing the importance of including culture into teaching EFL, gets the greatest mean score (MA1 = 4.53). The high level of teachers' awareness reveals that they approved the integration of culture teaching in language teaching. The other three items, focusing on the objectives of intercultural teaching, received high approval from the teachers. Teaching cultures to motivate students to study English was the most appreciated objective with the highest mean score (MA2= 4.21) while developing intercultural knowledge and developing ICC for students a got lower score (MA6 $=4.18$ and MA8 $=4.15$ respectively). Hence, the teachers agreed on the roles of intercultural teaching but secondary to language teaching and teaching intercultural knowledge was prioritized over developing students' IC or ICC.

Table 4

Teachers' beliefs in integrating culture into teaching EFL

\begin{tabular}{lc}
\hline \multicolumn{1}{c}{ Items } & Mean \\
\hline A1 Culture should be an integral part of English lessons. & 4.53 \\
A2 Integrating culture motivates students to study a foreign language better. & 4.21 \\
A6 Integrating culture fosters students' understanding of foreign cultures. & 4.18 \\
A8 Integrating culture fosters students' communicative competence with people & 4.15 \\
coming from other cultures. & \\
\hline
\end{tabular}

Since open-ended questions were not obligatory, only six teachers gave their responses, which were categorized and coded as presented in Table 5. Teachers agreed that the most dominating objective of intercultural teaching was to develop students' intercultural knowledge because knowing about "their selfness" and "the otherness" would help to avoid culture shocks in intercultural communication (teachers T49, T56, and T75). Besides, Teacher T5 and Teacher T23 shared the same idea that culture should be added to facilitate language learning. Noticeably, Teacher T71 mentioned that intercultural teaching should target fostering positive attitudes towards foreign cultures. Proven from qualitative reports, teachers valued the integration of culture to facilitate language learning. In general, they agreed that intercultural integration should focus on both home and foreign cultures, both "small c" and "big C" culture to build students' intercultural knowledge and attitudes. 
Table 5

Coding of teachers' beliefs in integrating culture into teaching EFL

\begin{tabular}{llll}
\hline \multicolumn{1}{c}{ Category } & Code & Freq & Teacher Code \\
\hline Language and culture link & Language and culture link & 1 & T5 \\
Developing CC & Motivative factor to study language & 1 & T23 \\
& Developing intercultural knowledge & 3 & T49, T56, T75 \\
\multirow{2}{*}{ Developing IC } & Developing intercultural attitudes & 1 & T71 \\
\hline
\end{tabular}

As presented in Table 6 , teachers' perceived practices attain a fairly high mean score (M $=3.8169$ ).

Table 6

Teachers' perceived practices of integrating culture into teaching EFL

\begin{tabular}{ll}
\hline \multicolumn{1}{c}{ Items } & Mean \\
\hline A3 Culture should be integrated into foreign language lessons as early as possible. & 4.00 \\
A5 Culture can be integrated into language lessons in form of skill activities. & 3.98 \\
A7 Integrating culture can be done in form of intra and extra curriculum activities. & 3.86 \\
A9 Integrating culture can be organized by using internet applications (e.g. & 3.70 \\
YouTube, Zalo, Facebook, etc.) & 3.68 \\
A10 Integrating culture should take students' home culture into account. & 3.94 \\
A11 Integrating culture should include students' home culture. & 3.55 \\
A12 Integrating culture should involve clearly stated lesson objectives. & \\
\hline
\end{tabular}

Interestingly, Item A3 "culture should be integrated into foreign language lessons as early as possible" received the greatest approval from the teachers (MA3 $=4.0$ ). It was assumed that they supported intercultural integration regardless of students' low language proficiency. In relation to how culture should be taught, a great deal of teachers agreed that culture should be integrated into foreign language lessons in form of language skill activities (MA5 = 3.98). The role of home culture was emphasized (M11 = 3.94), but the way to include home cultures was less confirmed (M10 = 3.68). The teachers were willing to use social media like Facebook or Zalo to teach culture in an interactive way $(\mathrm{M} 9=3.70)$ but still favoured offline or face to face activities (MA7 $=3.86$ ). To conclude, teachers were receptive to intercultural integration, but they were less likely to acknowledge intercultural objectives in their EFL lessons.

\section{Results of the Second Research Question}

Descriptive statistics of teachers' intercultural teaching practices is summarized in Figure 1. The mean comparing the four clusters displays a downward trend from teaching intercultural knowledge $(\mathrm{M} 1=3.5971)$ to building intercultural attitudes $(\mathrm{M} 3=$ 2.7505), and developing intercultural skills $(\mathrm{M} 4=1.8708)$, from conducting teachercentred activities to student-centred ones $(\mathrm{M} 1=3.5971$ and $\mathrm{M} 2=2.8446)$. 


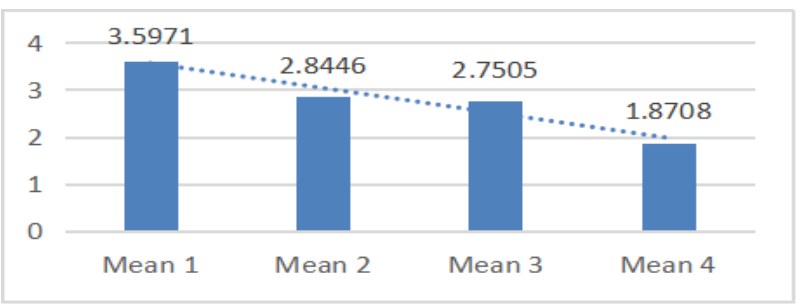

Figure 1

Teachers' IC teaching practices

As shown in Table 7, the difference among the four values is statistically proven by One-way ANOVA $(\mathrm{F}=153.644, \mathrm{df}=3, \mathrm{p}=.000)$.

Table 7

Mean difference among the four clusters of intercultural teaching activities

\begin{tabular}{llllll}
\hline & Sum of Squares & df & Mean Square & F & Sig. $\left.*^{*}\right)$ \\
\hline Between Groups & 150.362 & 3 & 50.121 & 153.644 & .000 \\
\hline
\end{tabular}

(*) The mean difference is significant at the 0.05 level.

Mean scores of items describing intercultural teaching practices are presented in Table 8.

Table 8

Teachers' practices of integrating culture into teaching EFL

\begin{tabular}{lc}
\multicolumn{1}{c}{ Items } & Mean \\
\hline B1. I relate the cultural contents to what I have learned and experienced (about the foreign & 3.48 \\
cultures or countries). & 3.59 \\
B2. I provide my students with appropriate language (eg. terms, expressions, structures, stress, \\
intonations, etc.) used in different communicative situations. \\
B3. I help my students to learn about how to do things and behave in different social & 3.72 \\
interactions & 3.27 \\
B4. I ask my students to share aspects of their own culture in English. & 2.58 \\
B6. I ask my students to do kinds of projects to introduce their own (or local) culture to the \\
foreigners. \\
B7. I ask my students to explore an aspect of the foreign culture and present it to their friends. \\
B5. I mention the relativity of prejudices (e.g. Not all the British people are reserved; Not all \\
French are romantic; etc.) \\
B10. I decorate my classroom with posters/pictures/ornaments illustrating aspects of the foreign \\
culture. & 1.88 \\
B11. I use videos, CD-ROMs or the Internet to illustrate aspects of the foreign culture like \\
songs, films, fashions, festivals, etc. \\
B12. I also teach the similarities between the home and foreign cultures. \\
B13. I encourage the students to explore the causes of differences between home and foreign \\
cultures. \\
B14. I have my students approach to diverse cultural facts and notions to create positive \\
perspectives towards the differences. \\
B15. I get my students to evaluate their home and foreign culture from different views.
\end{tabular}

International Journal of Instruction, January2019 • Vol.12, No.1 
B8. I organize some simulated intercultural communicative activities like celebrating cultural events, role plays, solving cultural conflicts, etc. for students to practise linguistic and intercultural skills.

B9. I invite a person originating from the foreign countries to my class.

B16. I engage students into a chat group with foreigners to share their cultural knowledge and experience.

Regarding to intercultural knowledge, teacher-fronted activities were more common. Noteworthily, activities to deal with culture in communication and culture in language $(\mathrm{MB} 3=3.72$ and $\mathrm{MB} 2=3.59$ respectively) were more frequent than adding related cultural contents to language lessons $(\mathrm{MB} 1=3.48)$. Of student-centred activities, presenting and sharing home culture (MB4 = 3.27) were more dominant than participating in projects to introducing home culture to foreigners $(\mathrm{MB} 6=2.58)$ and exploring cultures $(\mathrm{MB} 7=2.68)$.

Among the activities to develop students' attitudes, three most frequent activities were comparing cultures $(\mathrm{MB} 12=3.36)$, using audio-visual aids to bring variety to the students $(\mathrm{MB} 11=3.17)$, and mentioning relativity of prejudices $(\mathrm{MB} 5=3.08)$. Other advanced activities (such as exploring the roots of differences, evaluating the differences, and forming positive perspectives towards the differences and diversities) rarely happened in the classes $(\mathrm{MB} 13=2.83, \mathrm{MB} 15=2.42$, and $\mathrm{MB} 14=2.52$ respectively). Displaying artefacts rarely took place $(\mathrm{MB} 10=1.88)$.

Finally, the three last activities to engage students into real or simulated intercultural communication to develop intercultural skills were never or rarely conducted. Simulated intercultural activities (i.e., celebrating cultural events, role plays, solving cultural conflicts) were infrequently conducted $(\mathrm{MB} 8=2.42)$; and activities engaging students into actual interactions by inviting guest speakers and joining chat groups were almost ignored $(\mathrm{MB} 9=1.57, \mathrm{MB} 16=1.62)$.

As quantitatively reported, intercultural activities were not often conducted in EFL classes. Intercultural teaching was more student-centred and knowledge-based. The preliminary finding from quantitative reports needed confirming and modifying by teachers' reports of their teaching experiences, which is shown in Table 9.

Table 9

Coding of intercultural teaching activities

\begin{tabular}{llll}
\hline \multicolumn{1}{c}{ Category } & Sub-category & Codes of IC teaching activities & Freq \\
\hline $\begin{array}{l}\text { Teaching } \\
\text { culture } \\
\text { explicitly }\end{array}$ & Teaching intercultural knowledge & Organizing Q-A games & 5 \\
& $\begin{array}{l}\text { Having students explore } \\
\text { intercultural knowledge } \\
\text { Developing intercultural skills }\end{array}$ & Using pictures to illustrate artefacts & 3 \\
\hline $\begin{array}{l}\text { Teaching } \\
\text { culture } \\
\text { implicitly }\end{array}$ & Teaching culture implicitly & $\begin{array}{l}\text { Embedding cultural contents in skill } \\
\text { lessons } \\
\text { Teaching culture accidentally }\end{array}$ & 2 \\
\hline
\end{tabular}

Besides explicit intercultural activities mentioned in the questionnaire, teachers stated that they taught cultures explicitly and implicitly. On the one hand, variety of explicit intercultural activities, such as Question and Answer games (Q and A games), drama, roleplay, fashion show, and using pictures to illustrate culture practices were conducted 
in classes. These activities were supportive to language learning and appropriate to the teaching contexts which were not rich in foreign and target cultures. On the other hand, teachers were inclined to teach culture implicitly. For instance, they introduced intercultural practices, such as festivals and celebrations to provide language input in skill lessons. From the teachers' reports, it is concluded that they managed to integrate cultures into teaching EFL by utilizing accessible resources and preferred intercultural knowledge transferring activities.

\section{Results of the Third Research Questions}

The effect of teachers' professional backgrounds: international experience, teaching experience, and graduate education on teachers' perceptions and practices of intercultural teaching are measured by One-way between-subject ANOVA and post hoc tests. The results are presented in Table 10.

Table 10

Supporting factors to intercultural integration

\begin{tabular}{llllll}
\hline Demographic factors & Variables & Mean Square & F & df & Sig. (*) \\
\hline Teaching experience & Perceptions & .256 & 1.487 & 1 & .226 \\
& Practices & .076 & .351 & 1 & .555 \\
International experience & Perceptions & .081 & .463 & 1 & .498 \\
& Practices & .323 & 1.501 & 1 & .223 \\
Graduate education & Perceptions & .173 & 1.001 & 1 & .320 \\
& Practices & .944 & 4.514 & 1 & $\mathbf{. 0 3 6}$ \\
\hline
\end{tabular}

(*) The mean difference is significant at the 0.05 level.

Table 10 proves that there is no significant effect of coursebook teaching on teachers' perceptions $(\mathrm{F}=1.487, \mathrm{p}=.226)$ and practices $(\mathrm{F}=.351, \mathrm{p}=.555)$. Similarly, the effects of international experience on their perceptions $(\mathrm{F}=.463, \mathrm{p}=.498)$ and practices $(\mathrm{F}=1.01, \mathrm{p}=.223)$ are not significant. Differently, graduate education in TESOL has meaningful impact on their intercultural teaching practices $(\mathrm{F}=4.514, \boldsymbol{p}=. \mathbf{0 3 6})$ but not on their perceptions $(\mathrm{F}=1.001, \mathrm{p}=.320)$. Since graduate education is the only supporting factor, it is not necessary to compute a post hoc test for the degree of effect.

In conclusion, teachers had good understanding of intercultural teaching roles and objectives, but they rarely conducted intercultural activities in their teaching practice. Intercultural teaching was more teacher-centred, knowledge-based, and topic dependent. Of the three factors, namely teaching experience, international experience, and graduate education, no factor has meaningful effect on teachers' teaching perceptions; the only supporting factor to their intercultural teaching practices is graduate education.

\section{DISCUSSION AND RECOMMENDATIONS}

\section{Problems with Intercultural Teaching Practices}

As previously mentioned, teachers had good perceptions of intercultural integration, but their practices were not sufficient. The problems with teachers' intercultural teaching practices should be identified.

First, IC had a humble position in comparison to CC in English teaching. Nguyen (2013) and Zhou (2011) found that teachers mainly focused on linguistic goals. As teachers admitted, they treated culture as contents or themes to teach language skills to develop 
students' CC, not ICC. Even for the Communication and Culture lessons, a newly-added sections focusing on culture in the experimental coursebooks, no clear intercultural objectives were officially mentioned in teachers' lesson plans (Chau and Truong, 2018). In alignment to Lázár (2007), Nguyen (2013), and Sercu et al. (2005), participating teachers found difficult to include intercultural instruction in their teaching due to a scarcity of intercultural contents, lack of interculturally-based activities, and rigidity of prescribed teaching schedule and content. That is why intercultural teaching is believed to be peripheral, incidental, and inferior to language teaching.

Second, intercultural teaching was traditional and insufficient. In compliance with Chau and Truong (2018), Gönen and Sağlam (2012), Sercu et al. (2005), and Zhou (2011), the participating teachers had good intercultural teaching awareness. Specifically, this study, in concurrence with Sercu et al. (2005) and Zhou (2011), confirmed the inclination of teacher-centeredness and knowledge transferring in intercultural teaching. Because building IC and intercultural identity is a social and personal process, which requires individual engagement, social interaction, and critical judgement, knowledge transferring is not effective and comprehensive enough (Crozet et al. 1999; Deardorff, 2006; Newton et al. 2010). Moreover, intercultural teaching techniques were divergent and inconsistent. Ho (2011) and Sercu et al. (2005) discovered that teachers preferred teaching "small c" cultures to "big C" cultures, but Lázár (2007) found the opposite. From quantitative and qualitative data, this research found that teachers managed to cover both "big C" and "small c" culture. Evidences of "big C" culture could be proven by the positive mean score of items $\mathrm{B} 1$ and $\mathrm{B} 11$, which relate teaching intercultural knowledge from teachers' knowledge and related materials $(\mathrm{MB} 1=3.48$ and $\mathrm{MB} 11=$ 3.17). In the same line, as responses to items B3 and B5, the presence of activities to deal with culture values and conducts were also positively reported $(\mathrm{MB} 3=3.72$ and MB5 = 3.08).

Finally, as Sercu et al. (2005) confirmed, intercultural teaching was dissociating because teachers brought cultural variety to the students just to familiarize them with foreign cultures rather than to foster their positive intercultural attitudes. Likewise, the participating teachers were in favor of simple and fun activities, namely comparing cultures and using audio-visual aids, but ignored advanced intercultural activities to build students' intercultural attitudes and skills. For these reasons, it is proven that teachers managed to integrate culture in EFL teaching but their implementation should be improved for developing learners' comprehensive ICC.

\section{Factors Supporting Intercultural Teaching Perceptions and Practices}

Among the three factors: teachers' graduate education, coursebook teaching, and foreign experience, only teachers' education had a meaningful impact on their teaching practices and none of them affected their beliefs and perceived practices. This finding is discussed in alignment with those of Gönen and Sağlam (2012), Lázár (2007), Sercu et al. (2005), and Zhou (2011).

Similar to Lázár (2007), Sercu et al. (2005), and Zhou (2011), this research appreciated the value of teacher education to intercultural teaching more than coursebook teaching 
and foreign visit. Particularly, Lázár (2007) and Sercu et al. (2005) proved that the effect of teachers' training surpassed that of international experience. Specifically, Lázár (2007) confirmed that even a 90-minute training session on intercultural teaching pedagogy could considerably improve teachers' practices of intercultural integration. Further explaining the non-effect of international experience, Sercu et al. (2005) stated that short international experience only formed a touristic view on cultures only, not IC. In argument for the effect of international experience, Zhou (2011) confirmed its immediate effect for fostering teachers' IC, which positively contributed to their intercultural teaching perceptions and practices. Not relating the teachers' IC, this research confirmed that a short visit to foreign countries, less than one week, did not have meaningful or direct impact on the teachers' perceptions and practices of intercultural integration.

Different from Gönen and Sağlam (2012), this research proved that coursebook teaching did not make meaningful differences to teachers' intercultural teaching practices. That's to say teachers using experimental and current coursebooks had similar practices of intercultural integration. The similarity of practices for different curriculum application was attributed to the lack of intercultural language activities designed in the coursebook or conducted in classes by the teachers. Since developing IC is a process of personal engagement in intercultural interaction, intercultural teaching is supposed to be more context-dependent than prescriptive. Therefore, there is no one-size-fits-all coursebooks with appropriate intercultural language activities for learners of different educational contexts. It is the teachers' role to modify the coursebook activities to exploit provided intercultural content to develop students' ICC since they are most acknowledgeable about their students' language proficiency, interests, and cultural identity.

To conclude, the positive impact of teachers' graduate education on their intercultural teaching confirmed the priority of teachers' education and training. Also, the non-effect of coursebook teaching implied that teachers did not deal with IC properly regardless of following their coursebook activities. Therefore, the recommendations for this situation are a complete synchronization of curriculum dealing with coursebooks, learners' outcomes, and teachers' intercultural teaching pedagogy (Chau \& Truong, 2018; Hoang, 2016; Lázár, 2007; Nguyen, 2013; Sercu et al., 2005; Zhou, 2011). In fact, the mismatch between curriculum objectives and teachers' implementation is due to the absence of intercultural teaching pedagogy training and official guidance for pre-service and inteachers (Chau \& Truong, 2018; Nguyen, 2013). If teachers had been enabled with intercultural teaching approach and acknowledged intercultural teaching objectives, they could have made intercultural integration more effective in their practices.

\section{CONCLUSION AND LIMITATION}

The present research is limited in two ways. First, the small amount of the teachers with international experiences, graduate education in TESOL, and teaching experiences of two coursebook versions in comparison to those of the other group negatively affected the inferential results in defining the supporting factors to teachers' intercultural teaching perceptions and practices. Second, data collected from the teacher questionnaire and open-ended questions were not versatile and objective enough. To 
improve research reliability and validity, quantitative data should be enriched with the researcher's class observation.

Despite some limitations, this research has obtained its own values in the field especially in the transitional period of the educational reform and in defining for a proper approach to integrate culture in teaching EFL in general education. Investigating the status of intercultural teaching, this research has led to three confirmations. First, teachers had good perceptions of intercultural integration, but it was rather treated as a mean to develop students' CC than as an end to develop their ICC. Second, while the intercultural objective in EFL teaching has been prescribed from the macro level, it was not focused in teachers' perceptions and practices. Third, it was not the teachers' international experience or the coursebook teaching, but the teachers' graduate education that had a positive impact on their intercultural teaching practices. From the problems of intercultural teaching perceptions and practices, it is assumed that intercultural integration was not implemented properly. Therefore, the teachers should be guided and trained on intercultural teaching pedagogy to utilise intercultural content and conduct suitable intercultural activities to foster students' ICC instead of CC.

\section{REFERENCES}

Arslangilay, A. S. (2018). The reflection of immigration on school culture: A qualitative Study. International Journal of Instruction, 11(2), 585-602. https://doi.org/10.12973/iji.2018.11240a

Borg, S. (2003). Teacher cognition in language teaching: A Review of Research on What Language Teachers Think, Know, Believe, and Do. Language Teaching, 36(2), 81-109. https://doi.org/10.1017/S0261444803001903

Byram, K. \& Kramsch, C. (2008). Why is it Difficult to Teach Language as Culture? The German Quarterly, 81(1), 20-34. https://doi.org/10.1111/j.1756-1183.2008.00005.x

Byram, M. (1997). Teaching and assessing intercultural communicative competence. Clevedon: Multilingual Matters.

Byram, M. (2006). Language teaching for intercultural citizenship. Keynote address. Paper presented at the NZALT Conference, University of Auckland. 2-5.

Canale, M., \& Swain, M. (1981). A theoretical framework for communicative competence. In Palmer, A., Groot, P., \& Trosper, G. (Eds.), The construct validation of test of communicative competence, (pp.31-36).

Celce-Murcia, M., Dornyei, Z. \& Thurrell, S. (1995). Communicative Competence: A Pedagogically Motivated Model with Content Specifications. Issues in Applied Linguistics, 6 (2), 5-35.

Chau, T. H. H \& Truong, V. (2018). Developing intercultural competence for upper secondary students: Perspectives and practices. Kỷ yếu Hội thảo Quốc gia "Nghiên cứu Liên ngành về Ngôn ngũu và Giảng dạy Ngôn ngũu lần thứ III", 227-239. 
Crozet, C. Liddicoat, A. J. \& Lo Bianco, J. (1999) "Intercultural competence: From language policy to language education". In Lo Bianco, J., Liddicoat A. J., \& Crozet C. (Eds), Striving for the Third Place: Intercultural Competence Through Language Education. Canberra: Language Australia.

Deardorff, D. K. (2006). The Identification and Assessment of Intercultural Competence as a Student Outcome of Internationalization. Journal of Studies in International Education, 10 (3), 241-266.

Elo, S. \& Kyngäs, H. (2008). The Qualitative Content Analysis Process. Journal of Advanced Nursing, 62(1), 107-115. doi: 10.1111/j.1365-2648.2007.04569.x.

Fantini, A. E. (2006). Exploring and assessing intercultural competence. World Learning Publications. Retrieved from http://www.sit.edu/publications/docs/feil_research_report.pdf

Gönen, S., \& Sağlam, S. (2012). Teaching culture in the FL classroom: Teachers' perspectives. International Journal of Global Education, 1(3), 26-46. Retrieved from http://www.ijtase.net/ojs/index.php/ijge/article/view/143

Ho S. T. K. (2011). An investigation of intercultural teaching and learning in tertiary EFL classrooms in Vietnam. Electronic Theses and Dissertations. Victoria University of Wellington, Wellington, New Zealand. Retrieved from https://researcharchive.vuw.ac.nz/xmlui/bitstream/handle/10063/4447/thesis.pdf?sequen $\mathrm{ce}=2$

Hoang, V. V. (2016). Renovation in Curriculum Design and Textbook Development: An Effective Solution to Improving the Quality of English Teaching in Vietnamese Schools in the Context of Integration and Globalization. VNU Journal of Science: Education Research, 32(4), 9-20. Retrieved from https://js.vnu.edu.vn/ER/article/view/3845/3576

Hofstede, G. (1991). Cultures and organizations: Software of the mind, New York: McGraw-Hill.

Hung, B. P., Vien, T., \& Vu, N. N. (2018). Applying Cognitive Linguistics to Teaching English Prepositions: A Quasi-Experimental Study. International Journal of Instruction, 11(3), 327- 346. https://doi.org/10.12973/iji.2018.11323a

Lai, T. T. V. (2016). An evaluation of textbook English 10 - Volume 1 (experimental program) developed by Vietnamese Ministry of Education and training as seen from intercultural communicative EFL approach. Kỷ yếu Hội thảo Quốc gia 2016 "Nghiên cúu và giảng dạy Ngoại ngũu, ngôn ngũu, và quốc tế học tại Việt Nam”, 407-417.

Lázár, I. (2007). Incorporating culture-related activities in foreign language teaching. Retrieved from http://www. ecml.at/mtp2/lccinte/results/downloads/6-3-3.pdf

Le, V. C. (2004). From Ideology to Inquiry: Mediating Asian and Western Values in ELT Practice. The Journal of Asia TEFL, 1(1),167-183. 
Liddicoat, A. J. \& Crozet, C. (1997). Teaching culture as an integrated part of language teaching: An introduction. Australian Review of Applied Linguistics, Series S N14. Retrieved from https://files.eric.ed.gov/fulltext/ED421881.pdf

Liddicoat, A. J., Papademetre, L., Scarino, A., \& Kohler, M. (2003). Report on Intercultural Language Learning. Canberra, ACT: Commonwealth of Australia.

Newton, J. (2016). Cultivating intercultural competence in tertiary EFL programs. Crossing Borders in Language Teaching and Business Communication: Proceedings of the 11th ELT conference at AE CYUT. (1-22). Chaoyang University of Technology, Chaoyang, Taiwan, 27 May 2016. ISBN978-986-5631-24-6.

Newton, J., Yates, E., Shearn, S. \& Nowitzki, W. (2010). Intercultural communicative language teaching: Implications for effective teaching and learning. Wellington, New Zealand: Ministry of Education.

Nguyen, T. L. (2013). Integrating culture into Vietnamese university EFL teaching: A critical ethnography study. Electronic Theses and Dissertations. Auckland University of Technology, New Zealand. Retrieved from http://hdl.handle.net/10292/5975.

Nunan, D. (2003). The impact of English as a Global Language on Educational Policies and Practices in AsiaPacific Region. TESOL Quarterly, 37(4), 589-613.

Polit, D.F. \& Beck, C.T. (2012) Nursing research: Generating and assessing evidence for nursing practice (9th Ed.). Philadelphia: Wolters Kluwer Health Lippincott Williams \& Wilkins.

Sercu, L., Bandura, E., Castro, P., Davcheva, L., Laskaridou, C., Lundgren, U., Mendez García, M., \& Ryan, P. (2005). Foreign language teachers and intercultural competence: An international investigation. Clevedon: Multilingual Matters.

Stiftung, B. \& Cariplo, F. (2008). Intercultural competence - The key competence in the 21 st century. Retrieved from http://www.bertelsmannstiftung.de/fileadmin/files/BSt/Presse/imported/downloads/xcms_bst_dms_30238_3023 9_2.pdf.

Tran, T. Q., \& Duong, T. M. (2015). Intercultural Communicative Competence: A Vital Skill in the Context of ASEAN Economic Community. Global Journal of Foreign Language Teaching, 5(1), 15-22.

Tran, T. Q., \& Dang, H. V. (2014). Culture Teaching in English Language Teaching: Teachers' Beliefs and Their Classroom Practices. Korea TESOL Journal, 11(1), 207223.

Van Ek, J. (1986). Objectives for foreign language learning. Strasbourg: Council of Europe.

Zhou, Y. (2011). A study of Chinese university EFL teachers and their intercultural competence teaching. Electronic Theses and Dissertations. University of Winsor, Canada. Retrieved from https://scholar.uwindsor.ca/etd/428 